\title{
Buku Al-Arabiyah Baina Yadaik pada Program Intensif Language Learning Pusat Pengembangan Bahasa IAIN Padangsidimpuan
}

\section{Irsal Amin}

Institut Agama Islam Negeri Padangsidimpuan

Email: irsalamin@iain-padangsidimpuan.ac.id

$$
\begin{aligned}
& \text { ملخص } \\
& \text { الكتاب المدرسي أحد من الشروط في تخصيل برنامج التعليم بسب أن كتاب المدارس الجودة } \\
& \text { تسهل الطلبة في فهم بجالات التعليم التي علمه المدرس. وكتاب المدارس يسمي به كتاب الذي } \\
& \text { سيتعلم الطلاب في وقت معين. كتاب اللغة العربية بين يديك وهو كتاب الذي تدرس } \\
& \text { المحاضرين في مركز تطوير اللغات بجامعة فدانغ سيديمفوان الإسلامية الحكومية في بجال التعليم } \\
& \text { اللغة العربية حتي يحتاج إلى المفاهيم الواضحة في تطبيقها لتحصيلة اهداف التعليم. هذا }
\end{aligned}
$$

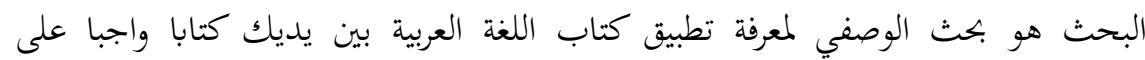

$$
\begin{aligned}
& \text { الطلاب. الفرد من هذا البحث هو كتاب ومفروده تطبيقها عند الدرس اللغة العربية. والطريقة } \\
& \text { التي تستخدم في جمع البيانات مقابلة وملاحظة وتوثيقة تتعلق عن تطبيق الكتاب وأما في } \\
& \text { تحليلها بطريقة تحليل المضمون من البيانات التي جمعت في البحث. وجد الباحث أن إجراءات } \\
& \text { التعليم منظما ومرتبا مرجوعا إلى الأنشطة التعليمية الموجودة منها الأنشطة الإفتتاحية }
\end{aligned}
$$

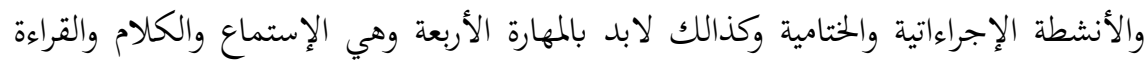

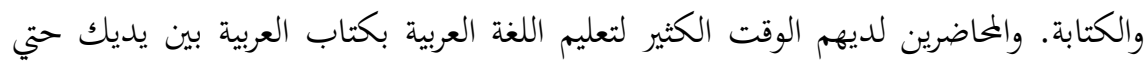

$$
\begin{aligned}
& \text { يتمكنهم في أنشطة المتنوعة لترقية مهارات الطلاب في اللغة العربية. } \\
& \text { الكلمة الإفتتاحية: كتاب المدارسي، البرنامج، المهارات }
\end{aligned}
$$

\section{Abstrak}

Buku ajar adalah salah satu penentu keberhasilan program pembelajaran, karena buku ajar yang berkualitas menjadikan peserta didik menjadi lebih mudah memahami materi ajar yang di ajarkan oleh pengajar. Buku ajar juga di sebut sebagai buku yang harus di pelajari oleh peserta didik dalam waktu yang di tentukan. Buku Al-arabiah baina yadaik adalah buku ajar yang diajarkan pada program intensif learning Pusat Pengembangan bahasa IAIN Padangsidimpuan pada mata kuliah Bahasa Arab sehingga membutuhkan konsep penerapan yang jelas sehingga mencapai tujuan yang terukur. Penelitian ini adalah penelitian deskriptif kualitatif yaitu menjelaskan bagimana penggunaan buku ajar $\mathrm{Al}$ arabiah baina yadaik ini sebagai buku wajib dalam mempelajari 
bahasa Arab di Pusat Pengembangan Bahasa IAIN Padangsidimpuan. Subjek penelitian pada penelitian ini adalah buku Al-arabiah baina yadaik, dan objeknya adalah penerapannya dalam mempelajari bahasa Arab. Metode pengumpulan data dalam penelitian ini dengan menggunakan wawancara, observasi dan studi dokumen yang berkaitan dengan buku Al-arabiah baina yadaik dan penerapannya, dan Setelah mendapatkan data penelitian, kemudian di analisa dengan metode analisis konten. Proses pelaksanaan pembelajaran berjalan dengan pengawasan yang jelas dan tersistem, dimana ada beberapa unsur pembelajaran yang harus terlaksana di dalamnya yang terdiri dari kegiatan pembuka, kegiatan inti dan penutup, serta harus memenuhi empat maharoh kebahasaan yang terdiri dari istima', kalam, kitabah dan qiroah. Kemudian keterjaminan ketercapian materi ajar dan pemahaman mahasiswa akan menjadi lebih terjamin karena proses menggunakan waktu yang cukup dan memadai sehingga pendistribusian materi ajar semakin matang dan para pengajar mempunyai banyak kesempatan untuk melakukan pengayaan yang variatif untuk menunjang pembelajaran bahasa Arab.

Kata Kunci: buku ajar, program,maharoh.

\section{PENDAHULUAN}

Program intensif belajar bahasa Arab di IAIN Padangsidimpuan adalah sebuah kewajiban pada setiap mahasiswa tanpa melihat latar belakang lulusan sekolah sebelumnya. Bahasa arab sebagai bahasa wajib yang harus di pahami oleh setiap mahasiswa untuk dijadikan sebagai bahasa harian selama satu tahun tinggal di asrama kampus. Pembelajaran bahasa arab di IAIN Padangsidimpuan dilaksanakan dengan program Insentif learning yaitu dilaksanakan setiap hari mulai dari senin sampai jum'at di bawah naungan Pusat Pengembangan Bahasa IAIN Padangsidimpuan. Program intensif learning yang dilaksanakan di IAIN Padangsidimpuan ini merupakan program satu-satunya di Indonesia dilingkungan Perguruan Tinggi Islam Negeri (PTKIN). Program intensif learning ini dibebankan kepada seluruh mahasiswa dan juga diwajibkan mengikuti ma'had jamiah.

Dalam mempelajari bahasa Arab Pusat pengembangan bahasa menggunakan buku Al-Arabiah Baina Yadaik sebagai buku ajar untuk mata kuliah Bahasa Arab. Buku ini adalah buku berbahasa Arab tanpa ada sedikitpun 
menggunakan bahasa Indonesia yang di tulis oleh Dr. Abdul Rahman Ibrahim Al-Fauzan. Buku ini adalah buku yang sengaja di tulis untuk mempelajari bahasa Arab dari dasar dengan menyajikan kemampuan kebahasaan, kemampuan komunikasi dan kemampuan kebudayaan. Buku ini sudah banyak digunakan di pondok pesanteren yang ada di Indonesia sebagai buku ajar untuk meningkatkan kemampuan bahasa Arab. selain digunakan secara resmi, buku ajar ini juga dapat dijadikan sebagai bahan untuk belajar bahasa Arab mandiri karena dapat di kembangkan untuk membuat test, soal, ujian dan test(Yuniar, Hidayati, and Anggita 2020:112). buku yang berkualitas sangat berpengaruh dalam menunjang proses pembelajaran baik pengajar maupun peserta didiknya (Pahlevi 2021:157). Di sisi lain menunjukkan bahwa sering kali keberadaan buku teks atau buku ajar kurang mencukupi pengetahuan akan perkembangan fisik dikarenakan isi materi yang terlalu singkat dan rangkuman materi yang minim (Nurdyansyah, Sugiarto, and Rais 2018: 201).

Mahasiswa yang mendaftar ke IAIN Padangsidimpuan tidak semua berasal dari sekolah Agama dan mampu membaca Al-Qur'an sehingga untuk mempelajari bahasa Arab tentunya membutuhkan kesesuain dengan keadaan peserta didik. Kesesuaian antara buku ajar dan peserta didik adalah sebuah kebutuhan dalam rangka untuk mencapai tujuan pengajaran yang di jadikan sebagai sumber materi ajar, menjadi refrensi buku baku untuk mata kuliah/pelajaran, sistematis dan sederhana dan mempunyai petunjuk pengajaraan (Sa'dun Akbar, 2013: 33). Mahasiswa yang bukan berasal dari sekolah berbasis non Agama atau pesanteren dan belum lancar membaca AlQur'an adalah sebagian besar mahasiswa yang mendaftar pada Fakultas Ekonomi dan Bisnis Islam dan sebagian kecil pada fakultas yang lain. Mahasiswa yang kuliah di Fakultas Ekonomi dan Bisnis Islam sebagaian besar berasal dari sekolah-sekolah berbasis Umum seperti Sekolah menengah Atas atau Sekolah Menengah Kejuruan dan diantara mereka bahkan masih ada yang tidak mengetahui sama sekali huruf-huruf hijaiyah.

\section{LANDASAN TEORI}

Buku menurut bahasa berasal dari bahasa Yunani yaitu Biblio, dan dalam bahasa jerman Bibliotec. Menurut ensiklopedia Indonesia bahwa buku adalah buku yang mencakup semua tulisan dan gambar yang di tulis dan dilukiskan atas segala macam lembaran papiru yaitu sejenis kertas yang terbuat dari bahanbahan rumput yang berasal dari sekitar sungai Nil yang dihaluskan dan di 
fungsikan sebagai sebagai alat tulis. Menurut Soetminah dalam Wiji Suwarno menyatakan bahwa buku adalah wadah informasi berupa lembaran kertas yang di cetak, dilipat dan di ikat mejadi satu pada punggungnya serta di beri sampul dalam aartian buku secara fisik (Wiji Suwarno, 2011: 50). Buku ajar juga dapat diartikan sebagai seperangkat sarana atau alat pembelajaran yang berisikan materi pelajaran, metode, batasan, dan cara mengevaluasi yang sudah di desain secara sistematis dan menarik dalam untuk mencapai tujuan pembelajaran yang sudah di tetapkan dalam kompetensi dasar dan standar kompetensi dengan segala kompleksitasnya (Chomsin, S. Widodo 2008: 40), serta sebagai buku materi pelajaran yang disusun secara sistematis yang digunakan oleh pengajar dan peserta didik dalam kegiatan belajar mengajar yang disusun oleh pakar dalam bidang materi tersebut berdasarkan kurikulum yang berlaku pada jenjang pendidikan tertentu yang bersifat sebagai penunjang dalam memahami materi ajar (Tian $2003: 12$ ).

Buku ajar dipahami sebagai alat pengajaran yang paling banyak digunakan di antara semua alat pengajaran lainnya (Hernowo, 2001: 88). Pengertian buku yang dimaksudkan bukan buku cetakan, melainkan buku bacaan yang diterbitkan oleh penerbit. Buku yang diterbitkan itu terdaftar secara resmi di Perpustakaan Nasional dengan memiliki nomor seri yang disebut International Series Book Number (ISBN). Buku yang ditulis tidak cukup sekedar terbit, kemudian diedarkan, lalu dijual. Yang terpenting dari kehadiran buku di tengah pembacanya adalah buku itu harus bergizi, tidak kering. Buku ajar memberikan ajaran dalam suatu bidang studi. Buku ajar adalah buku yang digunakan dalam proses kegiatan belajar. Buku ajar dikenal pula dengan sebutan buku teks, buku materi, buku paket, atau buku panduan belajar. Menilik isi dan luasnya buku teks sama saja dengan buku ajar. Jadi buku ajar yang dimaksudkan identik dengan buku teks, buku paket, buku materi atau buku panduan belajar.

Buku ajar adalah panduan peserta didik dalam proses pembelajaran yang memuat materi ajar, kegiatan penyelidikan berdasarkan konsep informasi lainlain serta menjadi bacaan peserta didik ketika belajar disekolah ataupun di rumah (Trianto, 2007:74). Buku ajar yang diterbitkan oleh pemerintah dalam hal ini Kementerian Pendidikan Nasional dan Kementerian Agama (dulu Dinas Pendidikan Nasional dan Departemen Agama) disebarluarkan ke semua sekolah di tanah air sebagai buku pegangan wajib serta tidak diperdagangkan. Jadi, dalam menerangkan apa yang dimaksud dengan buku ajar, penulis mendasarkan diri pada teori-teori yang berhubungan dengan buku teks. 
Banyak ahli yang mengemukakan batasan tentang buku ajar (paket, teks) ini. Di antaranya Hall-Quest dalam buku Tarigan mengatakan “buku ajar adalah rekaman pemikiran rasial yang disusun buat maksud-maksud dan tujuan-tujuan instruksional". Ahli lain seperti Lange menyatakan "buku teks (ajar) adalah buku standar atau buku setiap cabang khusus studi dan terdiri dari dua tipe yaitu buku pokok atau utama dan suplemen atau tambahan". Lebih terperinci lagi Bacon mengemukakan bahwa "buku teks (ajar) buku yang dirancang buat penggunaan di kelas, dengan cermat disusun dan disiapkan oleh para pakar atau ahli dalam bidang itu dan dilengkapi dengan sarana-sarana pengajaran yang sesuai dan serasi" (Tarigan, 1986: 11). Buku ajar yang baik adalah buku ajar yang mencukupi pengetahuan yang dibutuhkan oleh pesertadidik dalam mengembangkan pola pikir siswa sehingga harus mempunyai isi yang lengkap dan rangkuman yang jelas yang bersifat memperjelas materi ajar yang harus di kuasai (Nurdyansyah, Sugiarto, dan Rais, 2018: 201).

Buckingham mengutarakan bahwa "buku teks (ajar) adalah sarana belajar yang bisa digunakan di sekolah-sekolah dan di perguruan tinggi untuk menunjang suatu program pengajaran dan pengertian modern dan yang umum dipahami". Hal senada juga terdapat dalam Wikipedia, "A textbook or coursebook is a manual of instruction in any branch of study. A textbook can also be any standard book on a subject, which is not necessarily used in a particular course. Textbooks are produced according to the demands of educational institutions". Berdasarkan pendapat para ahli di atas, dapat dikatakan buku ajar merupakan buku yang diterbitkan dan disebarluaskan oleh pemerintah (Kemendiknas dan Kemenag)) sebagai buku pelajaran dalam bidang studi tertentu, yang merupakan buku standar dan disusun oleh para pakar dalam bidang itu untuk maksud-maksud dan tujuan intruksional dilengkapi dengan sarana pengajaran yang serasi dan mudah dipahami oleh para pemakainya di sekolah-sekolah sehingga menunjang suatu program pengajaran.

Dalam perkembangannya buku ajar tidak lagi diterbitkan oleh pemerintah, melainkan oleh pihak swasta. Dalam kaitan ini, pemerintah hanya diberi wewenang untuk pengadaan buku ajar, bukan untuk penggandaannya. Selanjutnnya pemerintah menetapkan standar tertentu yang harus dipenuhi oleh setiap penerbitan buku yang akan digunakan oleh satuan pendidikan. Dalam hal ini standar tersebut ditetapkan dan dikeluarkan oleh Badan Standar Nasional Pendidikan (BSNP) (PERMEN No 192005 Pasal 43). Selain itu, dalam Permendiknas Nomor 2 Tahun 2008 Pasal 1 menjelaskan bahwa "Buku teks adalah buku acuan wajib untuk digunakan di satuan pendidikan dasar dan 
menengah atau perguruan tinggi yang memuat materi pembelajaran dalam rangka peningkatan keimanan, ketakwaan, akhlak mulia, dan kepribadian, penguasaan ilmu pengetahuan dan teknologi, peningkatan kepekaan dan kemampuan estetis, peningkatan kemampuan kinestetis dan kesehatan yang disusun berdasarkan standar nasional pendidikan" (PERMEN No 2 Tahun 2008 Pasal 1 dan 2).

Seperti terlihat dari namanya, buku ajar adalah jenis buku yang digunakan dalam aktivitas belajar dan mengajar. Prinsipnya semua buku dapat digunakan untuk bahan kajian pembelajaran. Namun, yang ingin disampaikan adalah pengertian buku ajar terkait dengan cara menyusun, penggunaannya dalam pembelajaran, dan penyebarannya, sehingga buku tersebut termasuk kategori buku ajar. Buku ajar disusun dengan alur dan logika sesuai dengan rencana pembelajaran. Buku ajar disusun sesuai kebutuhan belajar siswa atau mahasiswa. Buku ajar disusun untuk mencapai tujuan pembelajaran atau kompetensi tertentu.

Untuk menyempurnakan pengertian tentang buku ajar yang dimaksudkan dengan Kepmen No: 36/D/O/2001, Pasal 5, ayat 9 (a); “Buku ajar adalah buku pegangan untuk suatu mata kuliah yang ditulis dan disusun oleh pakar bidang terkait dan memenuhi kaidah buku teks serta diterbitkan secara resmi dan disebarluaskan". Kata kuncinya adalah buku ajar disusun sesuai dengan mata pelajaran/mata kuliah tertentu, diterbitkan secara resmi dan disebarluaskan, artinya buku tersebut haruslah ber- ISBN. Dalam melaksanakan proses pembelajaran harus menggunakan buku ideal untuk mendapatkan hasil yang ideal sebagai tujuan dari berlangsungnya program pembelajaran. Buku ajar yang ideal mempunyai kriteria sebagai berikut(D and tarigan 2009, hal. 22): 1) Buku ajar tersebur harus mempunyai landasan, prinsip dan sudut pandang tertentu yang melandasi konsep-konsep yang digunakan dalam buku teks harus jelas; 2) Isi buku ajar tersebut harus relevan dengan kurikulum yang ada; 3) Desai isi dan penyajian menarik pembaca untuk membacanya; 4) Isi memberikan motivasi kepada pembacanya; 5) Buku tersebut menjadi stimulasi bagi pembacanya; 6) Mempunyai ilustrasi yang menarik penggunanya; 6) Pemahaman harus di dahului komunikasi yang tepat; 7) Isi dapat menunjang materi yang lain; 8) Menghargai perbedaan individu; 9) Menghargai nilai yang berlaku di tengahtengah masyarakat; 10) Bahasa yang digunakan mempertimbangkan kemampuan linguistik peserta didik pemakainya; 11) Mempunyai konsep yang jelas sehingga tidak membingungkan peserta didik; 12) Point of view yang jelas 
Buku ajar yang baik adalah buku yang mempunyai standar yang jelas sehingga internalisasi pengetahuan, krakter dan budi pekerti kepada peserta didik benjalan sesuai dengan apa yang sudah di rencanakan. Buku ajar harus mengikuti kurikulum yang sudah di rencanakan sehingga tidak ada kesimpang siuran antara isi materi dan kurikulum. Selain isi materi yang terdapat pada buku ajar tentunya pengajar juga harus ikut mengembangkan dan menjadi pemeran utama dalam mendidik peserta didik yang melengkapi buku ajar tersebut. Buku adalah benda mati tentunya tidak dapat menyesuaikan diri dengan peserta didik yang akan mempelajarinya sehingga peran guru menjadi harus sangat dominan pada proses pembelajaran berlangsung sehingga proses memahamkan sesuai dengan kondisi tetap berjalan (Lelya Hilda, 2015: 17). Selain penyesuain oleh pengajar akan materi ajar yang terdapat dalam buku ajar juga harus memberikan dorongan berupa motivasi dalam proses pembelajaran berlangsung baik secara individu maupun secara bersama-sama, karena salah satu fungsi pengajar juga harus mempu memberikan motivasi (Tatta Herawati, 2016: 91.

Pusat pengembangan bahasa IAIN Padangsidimpuan selaku lembaga pembantu institusi dalam melaksanakan kegiatan program pengajaran bahasa Arab menggunakan buku ajar yang sudah tetap, dimana dalam melaksanakan pembelajaran bahasa Arab menggunakan buku Al-arabiyah Baina Yadaik yang di terbitkan oleh Maktabah Al-Ranis Al-Arabiah Lil Jami' sebagai bahan ajar yang di siapkan dan di desain untuk para pelajar non Arab. Buku ini di beri nama $A l$ arabiyah Baina Yadaik karena buku ini di siapkan berada antara pengajar dan peserta didik dalam mempelajari bahasa Arab sehingga jika diterjemahkan kalimat Al-arabiyah Baina Yadaik adalah Buku bahasa Arab di antara dua tangan yaitu tangan pengajar dan peserta didik, artinya bahwa buku ini disiapkan untuk pengajarnya yang berkaitan dengan bagaimana cara mengajarkan materi ajar, penjelasan tentang konten-konten secara rinci dan bentuk-bentuk evaluasi sesuai dengan materi ajarnya.

Buku ini di tulis dengan tiga komponen kompotensi dasar yang disebut dengan Silsilah fi ta'lim al-lughoh al-arabiah li ghoiri An-nathiqina biha yaitu (Mukhtar At-Thohir, 2007: iii) :

a. Komponen kompetensi kebahasaan (Al-Kifayah Al-Lughowiyah), yaitu komponen kompetensi kebahasaan yang empat (maharoh al-arba'ah) yang terdiri dari kompetensi Istima', kalam, qiroa'ah dan kitabah. Empat kompetensi ini adalah kompetensi yang harus dimiliki dan di kuasai oleh peserta didik yang mempelajari bahasa Arab. thu'aimah menjelaskan bahwa 
ke empat kompetensi inilah yang harus di wujudkan atas hadirnya materi ajar dalam setiap buku ajar bahasa Arab (Ahmad Fuad Efendi, 2012: 134). selain empat kompetensi diatas juga mencakup kepada anasir Al-lughoh (unsur bahasa) yaitu unsur aswat, mufrodat dan tarakib an-nahwiyah. pertama, ashwat yaitu berkaitan dengan pola-pola pengucapan huruf-huruf bahasa Arab yang berbeda-beda. Kedua, Al-mufrodat yaitu unsur yang berkaitan dengan (kosa kata) mencakup kepada ungkapan-ungkapan dari sebuah kata. Ketiga, tarakib an-nahwiyah yaitu yang berkaitan dengan ketata bahasaan.

b. Kompetensi komunikasi (Al-kifayah al-ittisholiah), yaitu pemerolehan atas kemampuan komunikasi dengan penutur asli (ahli lughoh) di tinjau dari segi kondisi masyarakat arab dalam melakukan komunikasi baik secara lisan maupun tulisan berdasarkan kebiasaan yang berlaku pada perpedaan unsur masyarakat yang ada.

c. Kompetensi budaya (Al-kifayah al-tsaqofiah), yaitu kemampuan memahami budaya bahasa yang berbeda-beda yang tergabung dalam budaya Arab-Islam dan budaya bahasa secara umum yang tidak menyalahi ajaran agama Islam.

Buku ajar Al-arabiyah Baina Yadaik memuat banyak konten yang menarik memperkenalkan budaya arab Islam yang mungkin saja sebelumnya belum di ketahui oleh peserta didik walaupun sudah belajar bahasa Arab sebelumnya di pondok Pesanteren. Buku ini sudah menyentuh modernisasi yang sudah up to date budaya Arab melalui konten materi ajar yang tersedia karena sudah menyentuh budaya atau keadaan yang mudah di pahami oleh peserta didik sekarang. Termasuk konten yang mengalami modernisasi budaya yang membantu siswa mengenali budaya arab modren adalah seperti "an-nafsi, alhayatu fi madinah, atsaru tsaqofah islamiah, al-ulama dan mudun muqoddastah (Binti Maghfiroh, 2019: 436). Pengembagan materi ajar dalam buku ini juga sangat konsisten mengikuti keinginan dan prinsip bahasa Arab itu sendiri dengan tetap mengacu pada empat maharoh bahasa yang ada yaitu istima', kalam, qiroah dan kitabah sehingga konten materinya berkembangan pada judul tidak pada tujuan (Muhammad Syaifullah, 2019: 142). Kemudian sudah banyak peneliti tentang penerapan buku ini dan hasilnya menunjukkan cukup efektif dalam rangkan untuk meningkatkan kompetensi kebahasaan yang empat (M. Ilham Mukhtar, 2018: 121).

\section{METODE PENELITIAN}


Penelitian ini adalah penelitian deskriptif kualitatif yaitu menjelaskan bagimana penggunaan buku ajar Al-arabiah baina yadaik ini sebagai buku wajib dalam mempelajari bahasa Arab di Pusat Pengembangan Bahasa IAIN Padangsidimpuan. Subjek penelitian pada penelitian ini adalah buku Al-arabiah baina yadaik, dan objeknya adalah penerapannya dalam mempelajari bahasa Arab. Metode pengumpulan data dalam penelitian ini dengan menggunakan wawancara, observasi dan studi dokumen yang berkaitan dengan buku Alarabiah baina yadaik dan penerapannya, dan Setelah mendapatkan data penelitian, kemudian di analisa dengan metode analisis konten.

\section{HASIL DAN PEMBAHASAN}

Setelah melakukan analisa dari data penelitian maka peneliti menemukan bahwa dalam pengajaran bahasa Arab di Pusat Pengembangan Bahasa IAIN Padangsidimpuan dengan mengolah materi ajar yang terdapat pada buku $\mathrm{Al}$ arabiah baina yadaik dengan membuat levelisasi materi ajar bahasa arab yang di sesuaikan dengan sistem kredit semester (SKS), maka levelisasi materi ajarnya sebagai berikut :

a. Bahasa Arab I yaitu Al-arabiyah Baina Yadaik Kitab At-thalib 1 jilid satu yang terdiri dari delapan wahdah yaitu wahdah 1-8.

b. Bahasa Arab II adalah Al-arabiyah Baina Yadaik Kitab At-thalib 1 jilid dua yang terdiri dari delapan wahdah yaitu wahdah 9-16.

c. Bahasa Arab III adalah Al-arabiyah Baina Yadaik 2 Kitab At-thalib 2 jilid satu yang terdiri dari delapan wahdah yaitu wahdah 1-8.

d. Bahasa Arab IV adalah Al-arabiyah Baina Yadaik 2 Kitab At-thalib 2 jilid dua yang terdiri dari delapan wahdah yaitu wahdah 9-16.

Materi ajar di distribusikan selama satu tahun atau dua semester yaitu semester satu dan dua. Pendistribusian materi ajar pada semester satu yang terdiri dari bahasa Arab satu dan dua dan pada semester dua yang terdiri dari bahasa arab tiga dan empat. Distribusi materi ajar secara rinci dapat di jelaskan sebagai berikut :

\begin{tabular}{cll}
\hline \hline NO & \multicolumn{1}{c}{ MATERI AJAR } & \multicolumn{1}{c}{ WAKTU } \\
\hline \hline 1. & Bahasa Arab I & 59 Tatap Muka \\
\hline 2. & Bahasa Arab II & 59 Tatap Muka \\
\hline 3. & Bahasa Arab III & 59 Tatap Muka \\
\hline 4. & Bahasa Arab IV & 59 Tatap Muka \\
\hline
\end{tabular}


Adapun Sistem tatap muka atau proses perkuliahan yang di laksanakan di dalam kelas di bimbing oleh satu orang dosen dengan ketentuan bahwa kegiatan tatap muka enam ratus menit setiap minggu, kegiatan tatap muka selama lima hari mulai dari hari senin sampai jum'at, Rasio Dosen dan mahasasiswa adalah satu dosen maksimal 26 mahasiswa, Durasi setiap tatap muka adalah 100 menit. Dan kemudian dalam menuntaskan program pengajaran bahasa Arab dibutuhkan pembagian waktu berupa jadwal perkuliahan yang jelas dan terarah. Jadwal kuliah Pusat pengembangan bahasa bersipat tetap dan tidak dapat di pindah-pindah atau di sesuaikan dan menggunakan sistem inpal. Dan adapun rincian jadwal kuliah adalah sebagai berikut:

\begin{tabular}{|c|c|c|c|}
\hline No & Jadwal & Sesi & Waktu \\
\hline \multirow{3}{*}{1} & \multirow{3}{*}{ Pagi } & $\mathrm{I}$ & $07.30 \mathrm{~s} / \mathrm{d} 09.10 \mathrm{WIB}$ \\
\hline & & II & $09.15 \mathrm{~s} / \mathrm{d} 10.50 \mathrm{WIB}$ \\
\hline & & III & $11.00 \mathrm{~s} / \mathrm{d} 12.30 \mathrm{WIB}$ \\
\hline \multirow{3}{*}{2} & \multirow{3}{*}{ Siang } & $\mathrm{I}$ & $12.45 \mathrm{~s} / \mathrm{d} 14.30 \mathrm{WIB}$ \\
\hline & & II & $14.35 \mathrm{~s} / \mathrm{d} 16.10 \mathrm{WIB}$ \\
\hline & & III & $16.30 \mathrm{~s} / \mathrm{d} 18.10 \mathrm{WIB}$ \\
\hline
\end{tabular}

Proses pembelajaran ini berjalan sesuai jadwal yang sudah tertera diatas pada kelas yang terdistribusi pada empat Fakultas, yaitu Fakultas Tarbiyah dan Ilmu Keguruan, Fakultas Ekonomi dan Bisnis Islam, Fakultas Syariah dan Ilmu Hukum, dan Fakultas Dakwah dan Ilmu Komunikasi.

Kemudian untuk mengetahui keberhasilan program pembelajaran bahasa Arab dilaksanakan proses evaluasi yang mencakup pada dua hal pokok, yaitu:

a. Evaluasi keberhasilan proses, yaitu: Evaluasi ini dilakukan untuk mengetahui dan memastikan bahwa proses pengajaran di kelas berjalan dengan lancar yaitu dosen benar mengajar di kelas dan memenuhi unsur-unsur pengajaran bahasa yang mencakup kegiatan pembuka, kegiatan inti dan kegiatan penutup dalam rangka untuk mencapai tujuan pembelajaran yang meliputi kepada Istima', Kalam, Qiroa;h dan Kitabah Evaluasi ini di laksanakan melalui observasi pengajaran yaitu untuk melakukan pengemabangan pengajaran.

b. Evaluasi keberhasilan studi mahasiswa. Proses evaluasi keberhasilan pembelajaran mahasiswa terdiri dari Ujian dan Quis. Ujian dapat dilaksanakan melalui tiga jenis, yaitu :

1. Ujian Mid Term Test dilaksanakan ketika proses perkuliahan sebannyak 28 kali tatap muka dan capaian meteri ajar 4 Bab (Wahdah). 
2. Ujian Final Test dilaksanakan ketika ketika proses perkuliahan sebannyak 59 kali tatap muka dan capaian meteri ajar 8 Bab (Wahdah).

3. Quis dilakasanakan oleh dosen pengampu mata kuliah sebelum atau sesudah Final test berlangsung.

Dari ketiga jenis bentuk penilaian akan di jumlahkan dalam bentuk akumulatif yang di konfersikan dengan angka dan huruf yang diperoleh dalam setiap level adalam komponen dan persentase yang berbeda-beda. Persentase penilaian tersebut yaitu Ujian Mid Term Test 30\%, Ujian Final Test 60\%, dan Quis 10\%. Dan ujian-ujian bahasa Arab ini dilaksanakan sebanyak delapan kali ujian setiap tahun akademiknya, mulai dari Bahasa Arab level I, II, III, IV. Adapun Bentuk ujian bahasa Arab dilakasanakan dalam bentuk ujian Kitabah/Qiroah, istima' dan kalam. Komponen ujian bahasa Arab, untuk ujian Kitabah dan Qiro'ah komponennya adalah: Mufrodat, Tarakib, Teks atau Hiwar. Ujian kalam komponennya terdiri dari Fasohah, Pemahaman, Mufrodat, Tarakib. Ujian istima' komponennya terdiri dari Aswat, tarokib, pemahaman, mufrodat. Penilaian yang dilaksanakan terhadap beban studi mahasiswa pada setiap level pembelajaran terdiri dari:

a. Kitabah dinilai dari kemampuan mahasiswa meyelesai soal-soal kitabah yang mencakup kitabah mufrodat, dan tarokib dan jenis tes laiinya yang di tujukan untuk menguji kemampuan kitabah.

b. Qiro'ah dinilai dari kemampuan mahasiswa dalam memahami qiroah dan jenis tes yang di tujukan untuk menguji kemampuan mahasiswa.

c. Istima' dinilai dari kemampuan mahasiswa dalam menidentifikasi aswat berbahasa arab dan isi rekaman soal dan jenis tes lainnya yang di tujukan untuk menguji kemampuan istima' mahasiswa.

d. Kalam dinilai dari kemampuan mahasiswa berbicara bahasa arab dengan bentuk hiwar, deskripsi gambar, dan jenis tes lainnya yang di tujukan untuk menguji kemampuan kalam mahasiswa.

e. Quis dinalai dari kemampuan mahasiswa dalam menyelesaikan tes mandiri yang dilakukan oleh deosen pengampu mata kuliah.

f. Standar penilaian nilai ujian setiap level materi ajar bahasa diperoleh berdasarkan derajat penguasaan dari rentangan 00,00 - 100,00 sebagaimana perkuliahan lainnya dengan nilai huruf A, B, C, D, E.

Dari penjelasan data diatas dapat di pahami bahwa proses pembelajaran bahasa Arab di pusat pengembangan bahasa IAIN Padangsidimpuan menganut 
sistem intenshif Learning, dimana perkuliahan dilaksanakan secara intensif setiap hari. Proses ini tentunya menjadi sebuah proses yang terukur dan terjamin dalam pengajaran bahasa Arab karena menjadikan bahasa Arab sebagai mata kuliah wajib kepada setiap mahasiswa yang mendaftar tanpa tidak melihat latar belakang mahasiswa tersebut. Jika dilihat dari input mahasiswa yang sangat heterogen manjadikan mahasiwa yang merasa sulit dalam mempelajarinya begitu juga merasa mudah, akantetapi dengan model pembelajaran intens menjadi tidak ada alasan untuk mengatakan tidak mampu dan paham terhadap bahasa Arab.

Dengan adanya levelisasai materi ajar bahasa Arab membuat proses pembelajaran yang terstruktur yaitu mulai dari materi dasar, menengah dan mahir. Klasifikasi materi ajar ini membuat adanya pengukuran yang jelas dan penyesuaian terhadap kemampuan mahasiswa yang menjadikan mahasiswa memahaminya secara berjenjang sehingga tidak ada pemaksaan dalam mempelajari bahasa Arab. Selain klasifikasi materi, proses pengajarannya dilaksanakan dalam waktu yang cukup dan memadai yaitu setiap level mencapai 59 kali tatap muka, artinya ada sekitar 59.000 menit atau setara dengan 98 jam sehingga sangat meyakinkan bahwa setiap mahasiswa yang mempelajari bahasa Arab akan mempu menguasainya dilihat dari waktu yang dimilikinya.

\section{KESIMPULAN}

Berdasarkan analisa data penelitian yang dilakukan oleh peneliti dapat disimpulkan bahwa proses pembelajaran bahasa Arab dengan menggunakan Buku Al-arabiah baina yadaik di pusat pengembangan Bahasa IAIN Padangsidimpuan terlaksana dengan baik dan terukur. Proses pelaksanaan pembelajaran berjalan dengan pengawasan yang jelas dan tersistem, dimana ada beberapa unsur pembelajaran yang harus terlaksana di dalamnya yang terdiri dari kegiatan pembuka, kegiatan inti dan penutup, serta harus memenuhi empat maharoh kebahasaan yang terdiri dari istima', kalam, kitabah dan qiroah. Kemudian keterjaminan ketercapian materi ajar dan pemahaman mahasiswa akan menjadi lebih terjamin karena proses menggunakan waktu yang cukup dan memadai sehingga pendistribusian materi ajar semakin matang dan para pengajar mempunyai banyak kesempatan untuk melakukan pengayaan yang variatif untuk menunjang pembelajaran bahasa Arab. 


\section{DAFTAR PUSTAKA}

Ahmad Fuad Effend. 2012. Metodologi Pegajaran Bahasa Arab. malang: Misykat.

Al-fauzan, Muhktar At-thohir Husain Abdur Rahman Bin Ibrahim. 2007. Silsilah Fi Ta'lim al-Lughoh al-Arabiah Li Ghoiri an-Nathiqina Bighairiha Al-Arabiah Baina Yadaik. Riyadh: Maktabah Al-ranis Al-arabiah liljami'.

A'yuni, Binti Maghfirotul. 2019. “Buku Ajar Arabiyah Baina Yadaik Sebagai Solusi Kreatif Mempelajari Budaya Arab Di Lingkungan Pondok Pesantren Salaf," 16.

Chomsin, and S Widodo. 2008. Panduan Menyusun Bahan Ajar Berbasis Kompetensi. Jakarta: PT Elex Media Komputindo.

D, Tarigan, and H.G tarigan. 2009. Telaah Buku Teks Bahasa Indonesia. Bandung: Angkasa.

Daulae, Hj. Tatta Herawati. 2016. “Pengaruh Motivasi Dan Metode Mengajar Terhadap Prestasi Mata Kuliah Hadits Mahasiswa Iain Padangsidimpuan." TAZKIR: Jurnal Penelitian Ilmu-ilmu Sosial dan Keislaman 2 (1): 91. https://doi.org/10.24952/tazkir.v2i1.404.

Hernowo. 2001. Mengikat Makna. Bandung: Kaifa.

Hilda, Lelya. 2015. “Internalisasi Nilai-Nilai Tauhid Pada Mata Pelajaran Sains Di SDIT Bunayya Padangsidimpuan." TAZKIR: Jurnal Penelitian Ilmu-ilmu Sosial dan Keislaman 1 (2): 17. https://doi.org/10.24952/tazkir.v1i2.359.

Menteri Pendidikan NasionaL and Republik Indonesia. 2008. “Peraturan Menteri Pendidikan Nasional Republik Indonesia Nomor 2 Tahun 2008 Tentang Buku."

Muchtar, M Ilham. n.d. “Penerapan Metode Al-'Arabiyyah Bayna Yadaik Dalam Pembelajaran Bahasa Arab Di Ma'had Al-Birr Makassar" 12 (1): 20.

Nurdyansyah, Nurdyansah, Riska Sugiarto, and Pandi Rais. 2018. "Pengembangan Buku Ajar Berbasis Majalah Anak Materi Wudlu Untuk Meningkatkan Pemahaman Siswa." Halaqa: Islamic Education Journal 2 (2): 201-12. https://doi.org/10.21070/halaqa.v2i2.1772.

Pahlevi, Riza. 2021. “Analisis Buku Al-'Arabiyyah Baina Yadaik Jilid I." al-Ittijah: Jurnal Keilmuan dan Kependidikan Bahasa Arab 12 (2): 157-76. https://doi.org/10.32678/al-ittijah.v12i2.3630. 
"Peraturan Pemerintah Republik Indonesia Nomor 19 Tahun 2005 Tentang Standar Nasional Pendidikan." 2005. Pemerintah Pusat.

Sa'dun Akbar. 2013. Instrumen Perangkat Pembelajaran. Bandung: Rosdakarya.

Syaifullah, Muhammad, and Nailul Izzah. 2019. "Kajian Teoritis Pengembangan Bahan Ajar Bahasa Arab." Arabiyatuna: Jurnal Bahasa Arab 3 (1): 127. https://doi.org/10.29240/jba.v3i1.764.

Tarigan. 1986. Telaah Buku Teks Bahasa Indonesia. Bandung: Angkasa.

Tian, Belawati. 2003. Pengembangan Bahan Ajar. Jakarta: Pusat Penerbitan Universitas Terbuka.

Trianto. 2007. Model Pembelajaran Terpadu Dalam Teori Dan Prakter. Jakarta: Prestasi Pustaka Publisher.

Wiji Suwarno. 2011. Perpustakaan \& Buku: Wacana Penulisan \& Penerbitan. Jogyakarta: Ar-Ruzz Media.

Yuniar, Yuniar, Fitri Hidayati, and Tiya Anggita. 2020. “Tatwir Barnamij Wondershare Quiz Creator 'ala al-Kitab al-'Arabiyyah baina Yadaik Kamasdar Ta'lim al-Mustaqil." Jurnal Al Bayan: Jurnal Jurusan Pendidikan Bahasa Arab 12 (1): 112-27. https://doi.org/10.24042/albayan.v12i1.6087. 